\title{
Evaluation of Allyl Isothiocyanate as a Soil Fumigant for Tomato (Lycopersicon esculentum Mill.) Production
}

\author{
Jialin Yu, ${ }^{1,2}$ Gary E. Vallad, ${ }^{2}$ and Nathan S. Boyd ${ }^{2, \dagger}$ \\ ${ }^{1}$ College of Forestry, Nanjing Forestry University, Nanjing, Jiangsu, 210037, China \\ ${ }^{2}$ Gulf Coast Research and Education Center, University of Florida, Balm, FL 33598, U.S.A.
}

\begin{abstract}
Fusarium wilt (Fusarium oxysporum f. sp. lycopersici), root-knot nematodes (Meloidogyne spp.), and purple nutsedge (Cyperus rotundus L.) are among the most damaging soilborne pests for tomato (Lycopersicon esculentum Mill.) production in the southeastern United States. Allyl isothiocyanate (allyl ITC) was evaluated as a potential fumigant alternative for control of soilborne pathogens, nematodes, and weeds. Shank- or drip-injected allyl ITC at rates ranging from 221 to $367 \mathrm{~kg} \mathrm{ha}^{-1}$ exhibited excellent performance, reducing the recovery of total $F$. oxysporum from

film (TIF) did not further reduce the recovery of $F$. oxysporum and various nematodes from soil treated with allyl ITC compared with virtually impermeable film (VIF). However, TIF mulch significantly improved $C$. rotundus control versus shank- or drip-injected allyl ITC treatments under VIF mulch. Overall, allyl ITC is an effective methyl bromide alternative against $F$. oxysporum, $C$. rotundus, and plant-parasitic nematodes Criconemella spp. and Hoplolaimus spp. in plasticulture tomato production.
\end{abstract} treated soils. Shank- or drip-injected allyl ITC at $367 \mathrm{~kg} \mathrm{ha}^{-1}$ provided equivalent control of $C$. rotundus compared with 1,3-dichloropropene + chloropicrin and metam potassium, respectively. Totally impermeable
Keywords: drip-application, Fusarium wilt, nematodes, plastic mulch, soil fumigant, vegetables
Tomato (Lycopersicon esculentum Mill.) is the most extensively cultivated and consumed vegetable crop in the southeastern United States (USDA 2010). Among the most detrimental soilborne pests, diseases, and weeds for tomato production in the southeastern United States are root-knot nematodes Meloidogyne incognita (Kofoid and White) Chitwood and M. arenaria (Neal) Chitwood; sting nematodes (Belonolaimus spp.); stubby-root nematodes (Trichodorus spp.), several Fusarium, Pythium, and Rhizoctonia spp.; as well as yellow (Cyperus esculentus L.) and purple (C. rotundus L.) nutsedges. Tomato production techniques include the application of broadspectrum soil fumigants in raised beds under plastic polyethylene mulch. For many years, methyl bromide (MB) was extensively applied under plastic mulch in raised beds to provide effective control of bacteria, insects, fungi, plant-parasitic nematodes, soilborne viruses, and weeds (Schneider et al. 2003; Zasada et al. 2010). However, MB was classified as an ozone-depleting chemical in 1993 under the Montreal Protocol and was phased out in the United States in January 2005 (EPA 2018). Since that time, growers have adopted alternative fumigants for pest control.

Several fumigants have been identified as potential MB alternatives. At present, registered alternatives include 1,3-dichloropropene (1,3-D), chloropicrin (Pic), dimethyl disulfide (DMDS), and methyl isothiocyanate (methyl ITC) generators such as metam potassium (Boyd et al. 2017; Dayton et al. 2017; Hutchinson et al. 2004; Yu et al. 2019a; Zasada et al. 2010). These fumigants can be used alone but more frequently are applied in combination or as sequential applications to broaden the pest control spectrum (Boyd et al. 2017; Hutchinson et al. 2004; Mao et al. 2012; Yu et al. 2019a,b; Zasada et al. 2010). It is generally acknowledged, however, that none of the fumigants exhibit the broad-spectrum efficacy of MB. Therefore, the search for effective, safe, and cost-effective fumigants is ongoing.

Allyl isothiocyanate (allyl ITC) is a naturally occurring compound found in Brassicaceae plants such as broccoli (Brassica oleracea L.)

${ }^{\dagger}$ Corresponding author: N. S. Boyd; nsboyd@ufl.edu

The author(s) declare no conflict of interest.

Accepted for publication 2 June 2019.

(C) 2019 The American Phytopathological Society
(Mithen et al. 2003), canola (B. napus L.) (Kirkegaard and Sarwar 1999), horseradish (Armoracia rusticana L.) (Wu et al. 2009), and white mustard (Sinapis alba L.) (Yu and Morishita 2014). It is the predominant ITC formed from hydrolysis of allyl glucosinolate (Brown and Morra 1996; Kirkegaard and Sarwar 1999). It rapidly degrades in soil and its half-life is reported from $20 \mathrm{~h}$ to $60 \mathrm{~h}$ (Borek et al. 1994). It also rapidly degrades when exposed to sunlight ( $<1$ day) and does not deplete the ozone layer or contribute to greenhouse gas production in the atmosphere. The short persistence and low toxicity (acute oral toxicity [50\% lethal dose] $=425.4 \mathrm{mg} \mathrm{kg}^{-1}$ ) make allyl ITC a safe fumigant for plasticulture vegetable production (Vig et al. 2009). Currently, allyl ITC is registered in the United States under the trade name Dominus (Isagro USA, Inc., Morrisville, NC). Allyl ITC is documented to be detrimental to insects (Wu et al. 2009), nematodes (Ren et al. 2018; Yu et al. 2005), soilborne fungi (Baggio et al. 2018), and weeds (Brown and Morra 1996; Ren et al. 2018). Baggio et al. (2018) reported that allyl ITC was effective for managing Macrophomina phaseolina (Tassi) Goidanich, causal agent of charcoal rot in strawberry (Fragariax ananassa D.).

Traditionally, growers used low-density polyethylene (LDPE) plastic film in vegetable production. Totally impermeable film (TIF) and virtually impermeable film (VIF) are less permeable to fumigants compared with LDPE (McAvoy and Freeman 2013) and have been used increasingly in recent years. TIF and VIF are manufactured by coextrusion containing multilayers with barrier polymers such as polyamide or ethyl vinyl alcohol. The differences in fumigant retention and pest control efficacy among these plastic films have been documented. For example, Austerweil et al. (2006) reported that the losses of methyl ITC were reduced by $40 \%$ under VIF mulch compared with LDPE mulch. Motis et al. (2003) reported that $25 \%$ of the labeled rate of MB under VIF provided similar level of C. esculentus control compared with a full rate under LDPE mulch. To our knowledge, information regarding soilborne pest control and crop productivity with allyl ITC under different plastic films in tomato production systems has not been previous reported.

Allyl ITC can be applied by conventional shank injection. However, the volatilization and distribution in the soil profile may be limited by its higher boiling point and lower vapor pressure (boiling point $=150$ to $151^{\circ} \mathrm{C}$, flash point $=47^{\circ} \mathrm{C}$, and vapor pressure $=$ $1.33 \mathrm{kPa}$ at $38.3^{\circ} \mathrm{C}$ ) compared with $\mathrm{MB}$. An alternative application method is applying allyl ITC with irrigation water through the drip 
irrigation systems. Applying soluble formulations through a drip irrigation system may be more economical and environmentally friendly, and reduce worker exposure (Ajwa et al. 2002). In addition, in the southern United States, growers often grow multiple crops in sequence using the same beds, drip tapes, and plastic mulches $(\mathrm{Yu}$ et al. 2018) and, therefore, value drip fumigation as an application technique between crops.

The objectives of the research were to determine soilborne pest control efficacy from shank- and drip-applied allyl ITC at different rates under TIF or VIF mulch on various nematodes, fungal pathogens, and weeds.

\section{Materials and Methods}

Experimental site. Six field research trials were conducted from January 2012 to December 2013 at the Gulf Coast Research and Education Center (GCREC) in Balm, FL $\left(27.76^{\circ} \mathrm{N}, 82.22^{\circ} \mathrm{W}\right)$. The soil type at the experimental site was characterized as a Myakka fine sand (Sandy, Siliceous Hyperthermic Oxyaquic Alorthod) with a $\mathrm{pH}$ of $6.8,98 \%$ sand, $1 \%$ silt, and $1 \%$ clay. Raised beds were formed using bed pressing equipment (Kennco Manufacturing, Ruskin, FL, U.S.A.) on $1.5-\mathrm{m}$ centers, with a height of $20 \mathrm{~cm}$, and were $81 \mathrm{~cm}$ wide at the base and $71 \mathrm{~cm}$ wide at the top. Two rows of drip tape with emitters every $30 \mathrm{~cm}$ and a flow rate of 0.95 liters $\mathrm{min}^{-1}$ $30 \mathrm{~m}^{-1}$ (Jain Irrigation Inc., Haines City, FL, U.S.A.) were installed $2.5 \mathrm{~cm}$ beneath the soil surface and centered $20 \mathrm{~cm}$ apart down the center of each bed.

Shank fumigation experiments. Three field research trials were conducted in spring and fall 2012 and spring 2013 at the GCREC in Balm, FL. Trials were established as a split-plot design with four blocks. The main plot consisted of three 45.6-m-long beds and the subplot was $22.8 \mathrm{~m}$ of a single raised bed. The main plot factor was plastic film treatments, including TIF (Berry Plastics Corp., Evansville, IN, U.S.A.) and VIF (Berry Plastics Corp.) plastic mulches. The subplot factor was the fumigant treatments, including allyl ITC at $183,211,275$, or $367 \mathrm{~kg} \mathrm{ha}^{-1} ; 1,3-\mathrm{D}$ at $112 \mathrm{~kg} \mathrm{ha}^{-1}+$ Pic (Pic-Clor 60; Soil Chem. Corp. DBA Cardinal Professional Products, Hollister, CA, U.S.A.) at $168 \mathrm{~kg} \mathrm{ha}^{-1}$; and a nonfumigated control in trial I; and allyl ITC at 183, 229, 275, or $367 \mathrm{~kg} \mathrm{ha}^{-1}$; 1,3-D at $134 \mathrm{~kg} \mathrm{ha}^{-1}+\mathrm{Pic}$ at $202 \mathrm{~kg} \mathrm{ha}^{-1}$; and a nonfumigated control in trials II and III. The fumigants were applied with a three-shank fumigation rig (Kennco Manufacturing, Ruskin, FL, U.S.A.), with shanks set to evenly distribute fumigant at the base of the bed. Tomato plants were transplanted in the center of the bed with $61-\mathrm{cm}$ spacing between the plants. Tomato plants were irrigated, fertilized, and managed for foliar pests as per industry standards in the region (Vallad et al. 2014). Fumigation dates and other details of the experiments are shown in Table 1.

Recoverable levels of total Fusarium oxysporum from soils were determined by collecting soil cores from each subplot using a standard soil core sampler $(2.5 \mathrm{~cm}$ in diameter by $30.5 \mathrm{~cm}$ in depth) prior to transplanting ( 3 and 4 weeks following fumigation for drip and shank fumigant trials, respectively). Three separate cores were collected to a 20.3-cm depth from bed centers within the center $3 \mathrm{~m}$ of each treated plot, discarding the top $5 \mathrm{~cm}$ of soil (approximately $20 \mathrm{~g}$ of soil per sample). Each soil sample was placed in individually labeled 16.5-by-14.9-cm plastic bags, mixed, and allowed to air dry at $24^{\circ} \mathrm{C}$ with the bag tops open for 1 week. After drying, three $2.5-\mathrm{g}$ subsamples were added to $10 \mathrm{ml}$ of sterile distilled water in individual test tubes, vortexed for $10 \mathrm{~s}$, and serial diluted 10-fold in sterile distilled water. A 200- $\mu$ l aliquot of each dilution was spread onto a plate of either Komada's or Malachite Green Agar at 2.5 ppm (MGA 2.5) (Castellá et al. 1997; Komada 1975) using an autoclavable plastic cell spreader (Fisher Scientific, Waltham, MA, U.S.A.). All plates were allowed to air dry and stored at room temperature in the dark. Total soil populations of $F$. oxysporum were enumerated after 7 days and converted to CFU per gram of soil based on average recovery across all three soil samples.

Various parasitic nematodes, including Belonolaimus, Criconemella, Hoplolaimus, Meloidogyne, Tylenchorhynchus, and Trichodorus spp., were counted at harvest from a composite of 15 random soil cores randomly collected near the base of plants using a standard soil core sampler $(2.5 \mathrm{~cm}$ in diameter by $30.5 \mathrm{~cm}$ in depth) to a $25-\mathrm{cm}$ depth from the soil surface. Soils were pooled and mixed by plot and nematodes were extracted from a 100-g subsample, based on a standard sieving and centrifugation procedure (Jenkins 1964) performed at the University of Florida Entomology and Nematology, Nematode Assay Lab (University of Florida, Gainesville, FL, U.S.A.).

The number of $C$. rotundus shoots emerging through the plastic mulch and in the planting hole was counted over the entire bed at 4 and 8 weeks after transplanting (WATP). Twenty tomato plants per plot were harvested on 21 May and 31 May in spring 2012, 31 October in fall 2012, and 23 May in spring 2013. All tomato fruit were graded prior to weighing as small $(<5.5 \mathrm{~cm}$ in diameter), medium $(5.5 \mathrm{~cm}<$ diameter $<6.5 \mathrm{~cm})$, large $(6.5 \mathrm{~cm}<$ diameter < $7 \mathrm{~cm})$, or extra large $(>7 \mathrm{~cm}$ in diameter).

Drip fumigation experiments. Three field research trials were conducted in spring and fall 2012 and spring 2013 at the GCREC in Balm, FL. Trials were established as a split-plot design with four blocks. The main plot consisted of three 45.6-m-long beds and the subplot was $22.8 \mathrm{~m}$ of a single raised bed. The main plot factor was the plastic film treatments, including TIF and VIF plastic mulches, while the subplot factor was the fumigation treatments, including allyl ITC at $138,211,275$, or $367 \mathrm{~kg} \mathrm{ha}^{-1}$; metam potassium at $390 \mathrm{~kg} \mathrm{ha}^{-1}$; and the nonfumigated control in trial I; and allyl ITC at $183,229,275$, or $367 \mathrm{~kg} \mathrm{ha}^{-1}$; metam potassium at $390 \mathrm{~kg}$ $\mathrm{ha}^{-1}$; and the nonfumigated control in trials II and III. Fumigant treatments were applied into soil beds covered with TIF or VIF plastic mulch through the drip tapes. Two high-flow drip tapes (0.9 liters/h/emitter on 30-cm emitter spacing) were installed, offset by $10 \mathrm{~cm}$ on each side of the bed center at a soil depth of $2.5 \mathrm{~cm}$ beneath the soil surface. The fumigant treatments were injected through drip tapes using an electric water pump with a maximum flow rate of 13.25 liters $\mathrm{min}^{-1}$ fitted to a manifold and adjusted to deliver fumigant treatments from a 151-liter recirculating tank in $25.7 \mathrm{~m}^{3}$ of water followed by 19 liters of water to flush the irrigation lines; each plot injection took approximately 60 to $75 \mathrm{~min}$ to complete.

Tomato plants were transplanted in the center of the bed with 61$\mathrm{cm}$ spacing between plants (Table 1). Dates of fumigation, tomato transplanting, and harvesting are shown in Table 1. The data of F. oxysporum, nematodes, $C$. rotundus density, and tomato yield were collected by using the method described previously. The number of $C$. rotundus growing through the plastic much was counted at 4 and 8 WATP. Twenty tomato plants per plot were harvested and fruit were graded by using the method described earlier.

Statistical analysis. Two-way analysis of variance was performed by the PROC GLIMMIX procedure in SAS (version 9.4; SAS Institute Inc., Cary, NC, U.S.A.) to test for the significance of plastic films, fumigant treatments, and their interactions for data collected in the shank and drip fumigation experiments. Seasons were analyzed separately because they were conducted as separate experiments; weather conditions, nematodes, disease incidences, and weed populations varied between seasons. Treatments were compared

Table 1. Dates of fumigation, tomato transplanting, and harvesting

\begin{tabular}{lllc}
\hline Experiment, run & $\begin{array}{c}\text { Fumigation } \\
\text { application }\end{array}$ & $\begin{array}{c}\text { Transplanting } \\
\text { date }\end{array}$ & $\begin{array}{c}\text { Harvesting } \\
\text { date }\end{array}$ \\
\hline $\begin{array}{l}\text { Shank fumigation } \\
\text { Trial I }\end{array}$ & 12 January & 15 February & $\begin{array}{c}\text { 21 May and } \\
\text { 31 May 2012 }\end{array}$ \\
Trial II & 21 August & 24 September & 3 January 2013 \\
Trial III & 9 January & 13 February & 23 May 2013 \\
$\begin{array}{l}\text { Drip fumigation } \\
\text { Trial I }\end{array}$ & 10 February & 6 March & 13 June 2012 \\
Trial II & 28 August & 25 September & 8 January 2013 \\
Trial III & 14 January & 13 February & 23 May 2013 \\
\hline
\end{tabular}


using the least squares means statement with the Tukey adjustment at $P=0.05$. Data were checked for normality and constant variance prior to analysis. Data such as $C$. rotundus control that were collected over time were analyzed using the repeated statement in SAS.

\section{Results}

Shank fumigation experiment. Allyl ITC at rates of 211, 271, and $367 \mathrm{~kg} \mathrm{ha}^{-1}$ was effective in controlling $F$. oxysporum (Table 2). In trial I, all rates of allyl ITC and 1,3-D + Pic significantly reduced $F$. oxysporum compared with the nonfumigated control. In trial III, a low rate of allyl ITC at $183 \mathrm{~kg} \mathrm{ha}^{-1}$ as well as 1,3-D + Pic were not effective. In trial III, application of allyl ITC at a rate of $367 \mathrm{~kg} \mathrm{ha}^{-1}$ provided better $F$. oxysporum control than $183 \mathrm{~kg}$ $\mathrm{ha}^{-1}$ or 1,3-D + Pic. There were no significant differences in $F$. oxysporum control between TIF and VIF.

All rates of allyl ITC effectively reduced Criconemella spp. compared with the nonfumigated control and there was no significant difference in Criconemella spp. control among the fumigant treatments (Table 2). However, none of the fumigant treatments reduced Meloidogyne and Belonolaimus spp. compared with the nonfumigated control. There were no differences in nematode control between VIF and TIF.

The densities of $C$. rotundus were averaged over dates because the time by treatment interaction was not significant in the repeated-measures analysis. Application of allyl ITC at rates of 211 and $367 \mathrm{~kg} \mathrm{ha}^{-1}$ significantly reduced $C$. rotundus in trial I (Table 2). None of the allyl ITC rates significantly reduced $C$. rotundus density compared with the nonfumigated control in trials II and III, though densities tended to decline with increasing rate. 1,3-D + Pic significantly reduced $C$. rotundus density in all trials. In addition, $C$. rotundus populations were 35 to $71 \%$ lower in TIF than VIF in all three trials.

In all trials, there were no consistent yield trends in the various grading categories and, therefore, only the total marketable yields are presented in Table 3. All fumigant treatments produced significantly higher total marketable yield (65 to $125 \%$ ) compared with the nonfumigated control in trial I. A similar trend was observed in trial II ( 7 to $25 \%$ yield increase) but not in trial III. There were no differences in yield between VIF and TIF in any trial.

Drip fumigation experiment. All fumigant treatments significantly reduced $F$. oxysporum compared with the nonfumigated control in all three trials (Table 4). All allyl ITC rates except for $183 \mathrm{~kg}$ $\mathrm{ha}^{-1}$ in trial II provided equal or greater control of $F$. oxysporum compared with metam potassium. The type of plastic film had no effect on the recovery of total $F$. oxysporum from soil.

Table 3. Effect of shank injection of allyl isothiocyanate (allyl ITC) and type of plastic film on tomato yield in field experiments conducted in Balm, FL ${ }^{\mathrm{w}}$

\begin{tabular}{|c|c|c|c|c|}
\hline \multirow[b]{2}{*}{ Treatment $^{\mathrm{x}}$} & \multirow{2}{*}{$\begin{array}{c}\text { Rate } \\
\left(\mathrm{kg} \mathrm{ha}^{-1}\right)\end{array}$} & \multicolumn{3}{|c|}{ Tomato yield $\left(\mathrm{kg} \mathrm{ha}^{-1}\right)$} \\
\hline & & Trial I & Trial II & Trial III \\
\hline \multicolumn{5}{|l|}{ Fumigant } \\
\hline Allyl ITC & 183 & $8,680 \mathrm{a}$ & 65,925 & 29,864 \\
\hline Allyl ITC & $229^{y}$ & $10,426 \mathrm{a}$ & 65,729 & 25,202 \\
\hline Allyl ITC & 275 & 7,654 a & 61,135 & 22,714 \\
\hline Allyl ITC & 367 & 9,812 a & 59,079 & 29,375 \\
\hline $1,3-\mathrm{D}+\mathrm{Pic}$ & $134+202^{z}$ & 9,723 a & 56,448 & 30,971 \\
\hline $\begin{array}{l}\text { Nonfumigated } \\
\text { control }\end{array}$ & 0 & $4,629 \mathrm{~b}$ & 52,790 & 25,391 \\
\hline \multicolumn{5}{|l|}{ Film } \\
\hline VIF & $\ldots$ & 8,191 & 61,212 & 25,670 \\
\hline TIF & $\ldots$ & 8,786 & 59,155 & 28,836 \\
\hline Fumigant & $\ldots$ & 0.0075 & 0.0523 & 0.25 \\
\hline Film & $\ldots$ & 0.1075 & 0.4465 & 0.1711 \\
\hline Fumigant $\times$ film & $\ldots$ & 0.9754 & 0.9591 & 0.2639 \\
\hline
\end{tabular}

${ }^{w}$ Treatment means separated with Tukey adjustment means comparison at the 0.05 significance level. Trials I, II, and III were conducted in spring and fall 2012 and spring 2013, respectively.

x Abbreviations: 1,3-D + Pic, 1,3-dichloropropene + chloropicrin, VIF = virtually impermeable film, and TIF $=$ totally impermeable film.

y Allyl ITC rate was $211 \mathrm{~kg} \mathrm{ha}^{-1}$ in trial I.

z $1,3-\mathrm{D}+$ Pic rate was $134+202 \mathrm{~kg} \mathrm{ha}^{-1}$ in trial I.

Table 2. Effect of shank injection of allyl isothiocyanate (allyl ITC) and type of plastic film on Fusarium oxysporum, nematodes, and Cyperus rotundus in field experiments conducted in Balm, $\mathrm{FL}^{\mathrm{t}}$

\begin{tabular}{|c|c|c|c|c|c|c|c|c|c|}
\hline \multirow[b]{3}{*}{ Treatment $^{w}$} & \multirow[b]{3}{*}{ Rate $^{x}$} & \multirow{2}{*}{\multicolumn{2}{|c|}{ F. oxysporum ${ }^{\mathrm{v}}$}} & \multicolumn{3}{|c|}{ Nematodes per $100 \mathrm{~cm}^{3}$ of soil } & & & \\
\hline & & & & \multirow{2}{*}{$\frac{B e l}{\text { Trial I }}$} & \multirow{2}{*}{$\frac{C r i}{\text { Trial I }}$} & \multirow{2}{*}{$\frac{M e l}{\text { Trial I }}$} & \multicolumn{3}{|c|}{ C. rotundus shoots $\mathbf{m}^{-2}$} \\
\hline & & Trial I & Trial III & & & & Trial I & Trial II & Trial III \\
\hline \multicolumn{10}{|l|}{ Fumigant } \\
\hline Allyl ITC & 183 & $1.80 \mathrm{~b}$ & $2.79 \mathrm{ab}$ & 11.2 & $2.1 \mathrm{~b}$ & 23.5 & $17.0 \mathrm{ab}$ & $9.1 \mathrm{ab}$ & $11.1 \mathrm{a}$ \\
\hline Allyl ITC & $229^{y}$ & $1.49 \mathrm{~b}$ & $2.64 \mathrm{bc}$ & 8.3 & $1.8 \mathrm{~b}$ & 45.0 & $9.4 \mathrm{bc}$ & $8.5 \mathrm{ab}$ & $9.7 \mathrm{ab}$ \\
\hline Allyl ITC & 275 & $1.57 \mathrm{~b}$ & $2.66 \mathrm{bc}$ & 7.9 & $3.6 \mathrm{~b}$ & 22.9 & $15.4 \mathrm{ab}$ & $8.2 \mathrm{ab}$ & $9.8 \mathrm{ab}$ \\
\hline Allyl ITC & 367 & $1.57 \mathrm{~b}$ & $2.37 \mathrm{c}$ & 6.6 & $1.5 \mathrm{~b}$ & 25.3 & $8.2 \mathrm{bc}$ & $6.7 \mathrm{ab}$ & $7.3 \mathrm{ab}$ \\
\hline $1,3-\mathrm{D}+\mathrm{Pic}$ & $134+202^{z}$ & $1.97 \mathrm{~b}$ & $2.91 \mathrm{ab}$ & 7.3 & $2.1 \mathrm{~b}$ & 11.3 & $4.7 \mathrm{c}$ & $4.1 \mathrm{~b}$ & $5.2 \mathrm{~b}$ \\
\hline $\mathrm{Ctrl}$ & 0 & $2.83 \mathrm{a}$ & $3.07 \mathrm{a}$ & 10.5 & $26.2 \mathrm{a}$ & 32.0 & $28.3 \mathrm{a}$ & $10.6 \mathrm{a}$ & $12.7 \mathrm{a}$ \\
\hline \multicolumn{10}{|l|}{ Film } \\
\hline VIF & $\ldots$ & 2.13 & 2.76 & 7.8 & 4.6 & 25.0 & $21.8 \mathrm{a}$ & $9.7 \mathrm{a}$ & $11.3 \mathrm{a}$ \\
\hline TIF & $\ldots$ & 1.61 & 2.72 & 9.3 & 2.3 & 24.2 & $6.4 \mathrm{~b}$ & $6.1 \mathrm{~b}$ & $7.3 \mathrm{~b}$ \\
\hline Fumigant & $\ldots$ & 0.0007 & 0.0152 & 0.9095 & 0.0002 & 0.4449 & 0.0062 & 0.0461 & 0.0047 \\
\hline Film & $\ldots$ & 0.1124 & 0.8079 & 0.6787 & 0.0529 & 0.9471 & 0.0324 & 0.0030 & 0.0005 \\
\hline Fum $\times$ film & $\ldots$ & 0.3790 & 0.1276 & 0.9388 & 0.2831 & 0.3315 & 0.3325 & 0.3152 & 0.0570 \\
\hline $\begin{array}{l}\text { Treatment me } \\
\text { did not differ } \\
\text { detected in tri } \\
\text { II and III. Rec } \\
\text { were counted } \\
\text { u Species of Be } \\
\text { v F. oxysporum } \\
\text { w Abbreviation } \\
\text { and Fum = fu } \\
\text { x Rate in kilogr } \\
\text { y Allyl ITC rate } \\
\text { z } 1,3-\mathrm{D}+\text { Pic r }\end{array}$ & 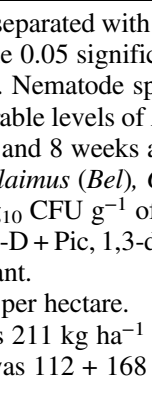 & $\begin{array}{l}\text { ey adjustn } \\
\text { level. Tr } \\
\text {, includin } \\
\text { ysporum } \\
\text { spansplant } \\
\text { nemella ( } \\
\text {. } \\
\text { ropropen }\end{array}$ & $\begin{array}{l}\text { heans comp } \\
\text { II, and III } \\
\text { loidogyne, } \\
\text { determined } \\
\text { and Meloid } \\
\text { loropicrin, }\end{array}$ & $\begin{array}{l}\mathrm{n} \text { at the } 0.0 \\
\text { conducted } \\
\text { nolaimus, } \\
\text { to transpla } \\
e(\mathrm{Mel}) \text {. } \\
=\text { nonfumig }\end{array}$ & $\begin{array}{l}\text { nificance } 1 \\
\text { pring and } \mathrm{f} \\
\text { riconemel } \\
\text {, parasitic }\end{array}$ & $\begin{array}{l}\text { Within eac } \\
12 \text { and sp } \\
\text { p., were de } \\
\text { todes were }\end{array}$ & $\begin{array}{l}\text { tment, val } \\
013 \text {, respe } \\
\text { d in trial I } \\
\text { ted at har }\end{array}$ & $\begin{array}{l}\text { llowed by } \\
\text { ly. } F \text {. oxys } \\
\text { were not d } \\
\text { g, and } C .\end{array}$ & $\begin{array}{l}\text { ame letter } \\
n \text { was not } \\
\mathrm{d} \text { in trials } \\
\text { lus shoots }\end{array}$ \\
\hline
\end{tabular}


The experimental site was infested by Belonolaimus, Criconemella, and Trichodorus spp. in trial I and Hoplolaimus, Meloidogyne, and Tylenchorhynchus spp. in trial III (Table 4). Only allyl ITC at $211 \mathrm{~kg} \mathrm{ha}^{-1}$ and the metam potassium fumigation treatment significantly reduced Criconemella spp. in trial I; none of the fumigant treatments affected Belonolaimus or Trichodorus spp. in this trial. All fumigant treatments significantly reduced Hoplolaimus spp. but did not affect other nematodes in trial III. The effect of plastic film on nematodes did not differ between TIF and VIF in either trial.

At the rates tested, allyl ITC and metam potassium significantly reduced $C$. rotundus density compared with the nonfumigated control in trials I and II (Table 4). In trial II, low rates of allyl ITC at 183 and $229 \mathrm{~kg} \mathrm{ha}^{-1}$ were less effective than metam potassium for controlling C. rotundus, while high rates of allyl ITC at 275 and $367 \mathrm{~kg} \mathrm{ha}^{-1}$ provided control similar to metam potassium. In trial III, C. rotundus densities were low and the nonfumigated control had 2.2 shoots $\mathrm{m}^{-2}$. TIF mulch resulted in lower $C$. rotundus density than VIF mulch in trials I and II. There were no differences in C. rotundus density among fumigant treatments and nonfumigated control in trial III. In general, results showed that the TIF plastic mulch reduced $C$. rotundus density better than VIF. C. rotundus populations were 32 to $68 \%$ lower in TIF than VIF in all three trials.

There were no significant differences among treatments for various grading categories and, as a result, only the total marketable yields are presented (Table 5). Plastic film-fumigant interactions had no significant effect on tomato yield in trial I $(P=0.2323)$ and trial II $(P=0.8813)$ but had a significant effect in trial III $(P=$ $0.0198)$. In trials I and II, the total marketable yields were not statistically different among the fumigant treatments. In trial III, none of the fumigant treatments produced tomato yields that were significantly higher than the nonfumigated control, with the exception of allyl ITC at $229 \mathrm{~kg} \mathrm{ha}^{-1}$ under TIF.

\section{Discussion}

In the southern United States, tomato yield losses have frequently been associated with various nematodes and fungal pathogens, in which phytopathogenic forms of $F$. oxysporum and various nematodes such as Meloidogyne spp. have become particularly problematical for tomato production. Our results showed that $F$. oxysporum populations were effectively reduced by shank- or drip-applied allyl ITC, confirming the sensitivity of Fusarium spp. to this fumigant. Our findings suggest that allyl ITC would also be effective for managing tomato diseases caused by phytopathogenic forms of $F$. oxysporum such as formae speciales lycopersici and radicis-lycopersici. In previous investigations, Gilreath et al. (2003) reported that drip-injected allyl ITC + furfural was effective in reducing Fusarium wilt in tomato. Recently, Ren et al. (2018) reported that chisel-applied allyl ITC was effective against Fusarium, Phytophthora, and Pythium spp.

In this research, allyl ITC was observed to be effective against Criconemella spp. and Hoplolaimus spp. when it was drip- and shank-applied, respectively, but was ineffective against Belonolaimus, Meloidogyne, Trichodorus, and Tylenchorhynchus spp. In previous research, Gilreath et al. (2008) reported that dripinjected allyl ITC with furfural was ineffective in controlling Belonolaimus spp. in strawberry crops (Fragaria $\times$ ananassa (Weston) Duchesne). Previous researchers have also revealed the relatively poor activity of metam sodium, a methyl ITC generator, against Meloidogyne spp. (Desaeger et al. 2008; Locascio et al. 2000; Noling and Becker 1994).

TIF did not further reduce soil levels of $F$. oxysporum and various nematodes from allyl ITC over VIF mulch. Allyl ITC has relatively low volatility and the type of plastic film may have limited effect on allyl ITC retention. TIF improved $C$. rotundus control from shank- or drip-injected fumigant treatments compared with VIF. The improved nutsedge control under TIF is probably due to a stronger physical barrier to $C$. rotundus emergence, which kept the rigid shoots from penetrating the TIF plastic mulch. This finding agrees with those of McAvoy and Freeman (2013), who previously reported that the nonfumigated plots under TIF provided significantly greater C. esculentus L. control than nonfumigated plots under VIF in plasticulture tomato. The authors also reported that DMDS/Pic (79:21 [wt/wt]) rates could be reduced from a standard 468 liters $\mathrm{ha}^{-1}$ under VIF to 187 liters $\mathrm{ha}^{-1}$ under TIF while maintaining nutsedge control.

In the present research, $C$. rotundus populations varied among trials. The differences in $C$. rotundus densities among trials are likely due to specific site location of the experiment. At the rates tested,

Table 4. Effect of drip injection of allyl isothiocyanate (allyl ITC) and type of plastic film on Fusarium oxysporum, nematodes, and Cyperus rotundus in field experiments conducted in Balm, $\mathrm{FL}^{\mathrm{t}}$

\begin{tabular}{|c|c|c|c|c|c|c|c|c|c|c|c|c|c|}
\hline \multirow[b]{3}{*}{ Treatment $^{w}$} & \multirow[b]{3}{*}{ Rate $^{\mathrm{x}}$} & & & & \multicolumn{6}{|c|}{ Nematodes per $100 \mathrm{~cm}^{3}$ of soil } & & & \\
\hline & & \multicolumn{3}{|c|}{ F. oxysporum ${ }^{\mathrm{v}}$} & \multicolumn{3}{|c|}{ Trial I } & \multicolumn{3}{|c|}{ Trial III } & \multicolumn{3}{|c|}{ C. rotundus shoots $\mathrm{m}^{-2}$} \\
\hline & & Trial I & Trial II & Trial III & Bel & Cri & Tri & Hop & $T y l$ & Mel & Trial I & Trial II & Trial III \\
\hline \multicolumn{14}{|l|}{ Fumigant } \\
\hline Allyl ITC & $183^{y}$ & $1.41 \mathrm{~b}$ & $2.39 \mathrm{~b}$ & $42.6 \mathrm{~b}$ & 4.5 & $1.8 \mathrm{ab}$ & 0.3 & $1.9 \mathrm{bc}$ & 1.8 & 3.4 & $2.1 \mathrm{~b}$ & $6.1 \mathrm{~b}$ & 2.5 \\
\hline Allyl ITC & $229^{z}$ & $0.00 \mathrm{~d}$ & $1.66 \mathrm{c}$ & $82.9 \mathrm{~b}$ & 4.5 & $0.9 \mathrm{~b}$ & 2.1 & $2.3 \mathrm{~b}$ & 2.2 & 4.8 & $2.1 \mathrm{~b}$ & $7.2 \mathrm{~b}$ & 1.5 \\
\hline Allyl ITC & 275 & $0.58 \mathrm{~cd}$ & $0.77 \mathrm{c}$ & $28.9 \mathrm{~b}$ & 6.1 & $2.5 \mathrm{ab}$ & 1.3 & $2.4 \mathrm{~b}$ & 1.5 & 4.1 & $1.2 \mathrm{~b}$ & $4.1 \mathrm{bc}$ & 2.5 \\
\hline Allyl ITC & 367 & $0.32 \mathrm{~d}$ & $0.96 \mathrm{c}$ & $48.7 \mathrm{~b}$ & 3.8 & $1.9 \mathrm{ab}$ & 0.9 & $3.1 \mathrm{~b}$ & 2.9 & 3.8 & $1.3 \mathrm{~b}$ & $4.1 \mathrm{bc}$ & 2.9 \\
\hline MetPot & 390 & $0.95 \mathrm{bc}$ & $1.46 \mathrm{c}$ & $21.4 \mathrm{~b}$ & 9.7 & $1.1 \mathrm{~b}$ & 1.2 & $0.4 \mathrm{c}$ & 4.3 & 1.3 & $2.3 \mathrm{~b}$ & $1.7 \mathrm{c}$ & 0.6 \\
\hline Ctrl & 0 & $2.58 \mathrm{a}$ & $3.35 \mathrm{a}$ & $1,002.1 \mathrm{a}$ & 4.9 & $5.7 \mathrm{a}$ & 1.5 & $12.5 \mathrm{a}$ & 2.2 & 13.0 & $18.0 \mathrm{a}$ & $15.4 \mathrm{a}$ & 2.2 \\
\hline \multicolumn{14}{|l|}{ Film } \\
\hline VIF & $\ldots$ & 1.08 & 2.01 & 67.2 & 5.0 & 1.9 & 0.8 & 2.4 & 1.7 & 7.0 & $4.8 \mathrm{a}$ & $8.8 \mathrm{a}$ & 2.5 \\
\hline $\mathrm{TIF}$ & $\ldots$ & 0.86 & 2.25 & 71.8 & 5.7 & 2.7 & 1.6 & 3.0 & 3.3 & 3.2 & $1.5 \mathrm{~b}$ & $4.0 \mathrm{~b}$ & 1.7 \\
\hline Fumigant & $\ldots$ & $<0.0001$ & $<0.0001$ & 0.0192 & 0.8849 & 0.0265 & 0.3653 & 0.0003 & 0.8753 & 0.0912 & $<0.0001$ & $<0.0001$ & 0.2347 \\
\hline Film & $\ldots$ & 0.2208 & 0.1988 & 0.9175 & 0.8154 & 0.3343 & 0.1013 & 0.4734 & 0.1946 & 0.0943 & 0.0006 & $<0.0001$ & 0.1816 \\
\hline Fum $\times$ film & $\cdots$ & 0.8353 & 0.3051 & 0.7122 & 0.9457 & 0.3627 & 0.0213 & 0.2383 & 0.1582 & 0.0686 & 0.3501 & 0.0538 & 0.8815 \\
\hline
\end{tabular}

$\mathrm{t}$ Treatment means separated with Tukey adjustment means comparison at the 0.05 significance level. Within each treatment, values followed by the same letter did not differ at the 0.05 significance level. Trials I, II, and III were conducted in spring and fall of 2012 and spring 2013, respectively. Recoverable levels of $F$. oxysporum were determined prior to transplanting, parasitic nematodes were counted at harvesting, and C. rotundus shoots were counted at 4 and 8 weeks after transplanting.

" Species of Belonolaimus (Bel), Criconemella (Cri), Trichodorus (Tri), Hoplolaimus (Hop), Tylenchorhynchus (Tyl), and Meloidogyne (Mel).

${ }^{\vee}$ F. oxysporum $\left(\log _{10} \mathrm{CFU} \mathrm{g} \mathrm{g}^{-1}\right.$ of soil).

${ }^{\mathrm{w}}$ Abbreviations: MetPot $=$ metam potassium, $\mathrm{Ctrl}=$ nonfumigated control, VIF $=$ virtually impermeable film, $\mathrm{TIF}=$ totally impermeable film, and Fum $=$ fumigant.

${ }^{x}$ Rate in kilograms per hectare.

y Allyl ITC rate was $138 \mathrm{~kg} \mathrm{ha}^{-1}$ in trial I.

z Allyl ITC rate was $211 \mathrm{~kg} \mathrm{ha}^{-1}$ in trial I. 
shank-injected allyl ITC is generally less effective against $C$. rotundus compared with 1,3-D + Pic. However, the highest rate of allyl ITC at $367 \mathrm{~kg} \mathrm{ha}^{-1}$ provided statistically equivalent control of $C$. rotundus compared with 1,3-D + Pic. Moreover, our results showed that shank-injected allyl ITC exhibited similar efficacy compared with 1,3-D + Pic in terms of the control of F. oxysporum and nematodes.

In the drip fumigation experiment, at the rates evaluated, allyl ITC significantly reduced the $C$. rotundus densities in two of three trials. During all three tomato seasons, drip-injected allyl ITC at

Table 5. Effect of drip injection of allyl isothiocyanate (allyl ITC) and type of plastic film on tomato yield in field experiments conducted in Balm, FL ${ }^{w}$

\begin{tabular}{|c|c|c|c|c|c|}
\hline \multirow[b]{2}{*}{ Film $^{x}$} & \multirow[b]{2}{*}{ Fumigant } & \multirow[b]{2}{*}{ Rate $\left(\mathrm{kg} \mathrm{ha}^{-1}\right)$} & \multicolumn{3}{|c|}{ Tomato yield $\left(\mathrm{kg} \mathrm{ha}^{-1}\right)$} \\
\hline & & & Trial I & Trial II & Trial III \\
\hline \multirow[t]{6}{*}{$\overline{\mathrm{VIF}}$} & Allyl ITC & $183^{y}$ & 39,229 & 39,273 & $32,538 \mathrm{ab}$ \\
\hline & Allyl ITC & $229^{z}$ & 35,933 & 46,862 & $26,757 \mathrm{~b}$ \\
\hline & Allyl ITC & 275 & 41,702 & 45,261 & $26,131 \mathrm{~b}$ \\
\hline & Allyl ITC & 367 & 28,104 & 48,914 & $33,052 \mathrm{ab}$ \\
\hline & Metam potassium & 390 & 38,323 & 46,176 & $34,567 \mathrm{ab}$ \\
\hline & Nonfumigated control & $\ldots$ & 28,351 & 39,154 & $25,872 \mathrm{~b}$ \\
\hline \multirow[t]{6}{*}{ TIF } & Allyl ITC & 183 & 26,703 & 48,495 & $34,425 \mathrm{ab}$ \\
\hline & Allyl ITC & 229 & 33,735 & 46,527 & 43,156 a \\
\hline & Allyl ITC & 275 & 33,735 & 49,288 & $34,130 \mathrm{ab}$ \\
\hline & Allyl ITC & 367 & 37,416 & 50,981 & $34,476 \mathrm{ab}$ \\
\hline & Metam potassium & 390 & 39,065 & 49,593 & $35,181 \mathrm{ab}$ \\
\hline & Nonfumigated control & $\ldots$ & 33,048 & 42,591 & $25,399 \mathrm{~b}$ \\
\hline Fumigant & $\ldots$ & $\ldots$ & 0.5890 & 0.4400 & 0.0042 \\
\hline Film & $\ldots$ & $\ldots$ & 0.8265 & 0.1759 & 0.0068 \\
\hline $\begin{array}{l}\text { Fumigant } \\
\times \text { film }\end{array}$ & $\ldots$ & $\cdots$ & 0.2323 & 0.8813 & 0.0198 \\
\hline
\end{tabular}

${ }^{\mathrm{w}}$ Treatment means separated with Tukey adjustment means comparison at the 0.05 significance level. Values within the same column followed by the same letter did not differ at the 0.05 significance level. Trials I, II, and III were conducted in spring and fall 2012 and spring 2013, respectively.

x Abbreviations: VIF $=$ virtually impermeable film and TIF $=$ totally impermeable film.

y Allyl ITC rate was $138 \mathrm{~kg} \mathrm{ha}^{-1}$ in trial I.

z Allyl ITC rate was $211 \mathrm{~kg} \mathrm{ha}^{-1}$ in trial I.

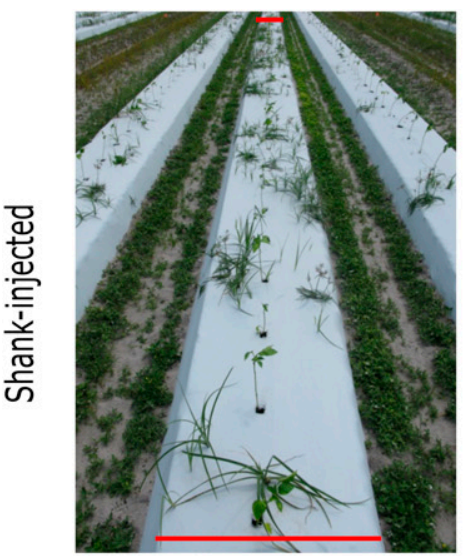

$183 \mathrm{~kg} \mathrm{ha}^{-1}$ allyl ITC

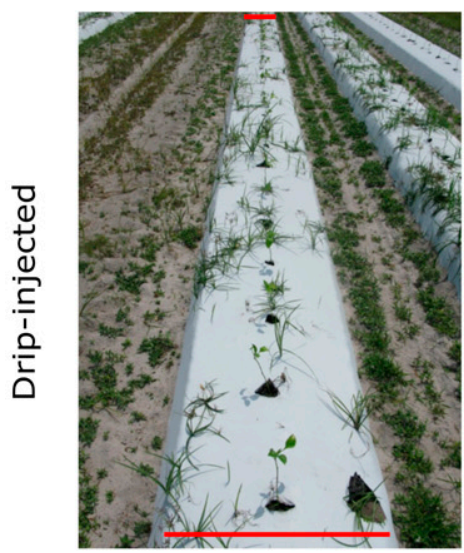

$183 \mathrm{~kg} \mathrm{ha}^{-1}$ allyl ITC

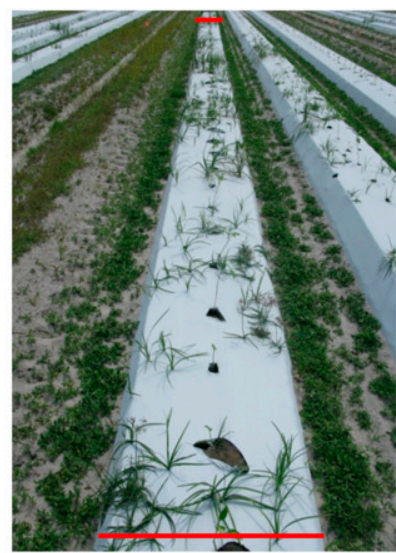

$275 \mathrm{~kg} \mathrm{ha}^{-1}$ allyl ITC

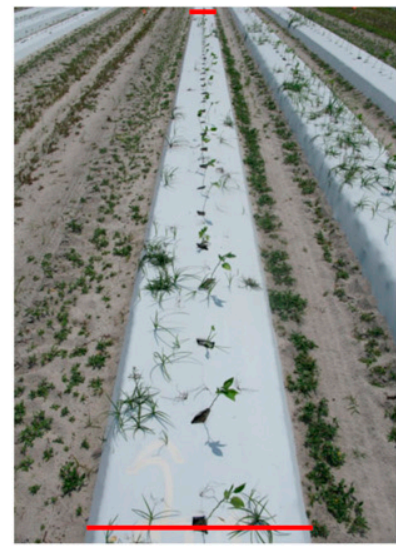

$275 \mathrm{~kg} \mathrm{ha}^{-1}$ allyl ITC
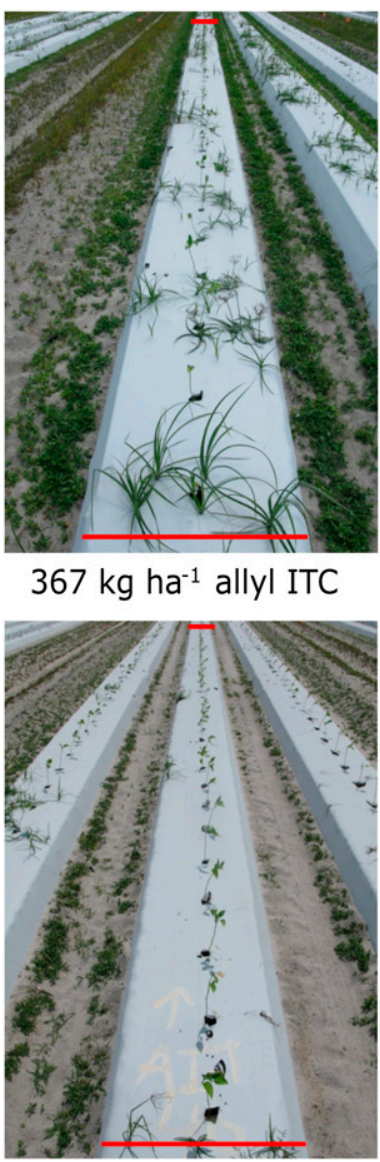

$367 \mathrm{~kg} \mathrm{ha}^{-1}$ allyl ITC $390 \mathrm{~kg} \mathrm{ha}^{-1}$ metam potassium

Fig. 1. Control of Cyperus rotundus in totally impermeable film plastic-mulched beds from shank- and drip-injected allyl isothiocyanate (allyl ITC) on the day of tomato transplanting in field experiments in Balm, FL. 
rates of 275 and $367 \mathrm{~kg} \mathrm{ha}^{-1}$ provided C. rotundus control comparable with metam potassium. Although differences in $C$. rotundus control between shank- and drip-application experiments were observed (Fig. 1), it is unknown which application method can provide better pest control because they have not been examined in the same experiment in the present research. Uniform distribution of allyl ITC in the soil profile is critical to improve pest control (Baggio et al. 2018). For controlling M. phaseolina, Baggio et al. (2018) recommended applying allyl ITC via shank with a dualport rig during the formation of new plastic-mulched beds, and applying allyl ITC through two drip tapes if the plastic beds need to be reused from the previous seasons.

The mode of action of allyl ITC for weed control is currently not known but it is suggested that allyl ITC interacts with glycolysisrelated enzymes during the weed seed germination or tuber sprouting and, thereby, prevents or delays seed germination or tuber sprouting (Drobnica et al. 1977). Previous research evaluated the efficacy of allyl ITC at concentrations ranging from 0 to $10,000 \mathrm{nmol} \mathrm{g}^{-1}$ soil for controlling large crabgrass (Digitaria sanguinalis (L.) Scop.), Palmer amaranth (Amaranthus palmeri (S.) Watson), and Cyperus esculentus in greenhouse conditions (Norsworthy and Meehan 2005). The authors reported that allyl ITC concentrations required to control $50 \%$ D. sanguinalis, A. palmeri, and C. esculentus were 982, 269, and 4,206 $\mathrm{nmol} \mathrm{g}^{-1}$ soil, respectively. In other research, allyl ITC at $932 \mathrm{~kg} \mathrm{ha}^{-1}$ provided effective control of D. sanguinalis, A. palmeri, and C. esculentus in field conditions (Bangarwa et al. 2011, 2012). Further research is needed to determine the control efficacy of allyl ITC on other weed species.

Previous studies have shown that fumigants such as 1,3-D, Pic, methyl iodide, and metam sodium, when applied singly, do not normally provide the same broad-spectrum pest control as MB (Boyd et al. 2017; Desaeger et al. 2008; Haar et al. 2003; Hutchinson et al. 2004). However, fumigant combinations such as 1,3-D + Pic (Desaeger et al. 2008; Hutchinson et al. 2004), methyl iodide + Pic (Hutchinson et al. 2004), and metam sodium + Pic (Haar et al. 2003; Hutchinson et al. 2004) proved to be as effective as MB in many situations. Perhaps combining allyl ITC with Pic could provide broad-spectrum control of nematodes, soilborne pathogens, and weeds and warrants further investigation.

The results suggested that shank- and drip-applied allyl ITC have the potential to improve the marketable tomato yield compared with the nonfumigated control. There were significant incidences of Fusarium crown and root rot $(F$. oxysporum $\mathrm{f}$. sp. radicis-lycopersici) in trial I in the shank fumigation experiment and trial III in the drip fumigation experiment, which had affected fruit yield in nonfumigated beds. However, plots treated with allyl ITC generally exhibited less disease incidence due to its efficacy on soilborne diseases and, as a result, produced greater marketable tomato yield compared with the nonfumigated control.

In summary, allyl ITC was highly effective at reducing soil levels of $F$. oxysporum. Allyl ITC controlled plant-parasitic nematodes Criconemella spp. and Hoplolaimus spp. but failed to effectively control Belonolaimus, Meloidogyne, Trichodorus, and Tylenchorhynchus spp. At the rates tested, shank-injected allyl ITC had similar efficacy compared with 1,3-D + Pic in reducing initial soil levels of $F$. oxysporum and the level of plant-parasitic nematodes Belonolaimus, Criconemella, and Meloidogyne spp. at the end of the season but was generally less effective compared with 1,3-D + Pic in controlling $C$. rotundus. Drip-injected allyl ITC at 275 and $367 \mathrm{~kg} \mathrm{ha}^{-1}$ provided $C$. rotundus control similar to metam potassium. TIF mulch improved the $C$. rotundus control from shank- or dripapplied allyl ITC compared with VIF mulch. However, the type of plastic film had little or no effect on soil levels of $F$. oxysporum and nematodes. Furthermore, allyl ITC seemed to increase the marketable yield of tomato. Additional research is needed to refine rates and application techniques to ensure effective pest control.

\section{Acknowledgments}

We thank H. Adkison, B. S. Hughes, S. Kalb, and the farm crew at GCREC for assistance with fumigation and data collection.

\section{Literature Cited}

Ajwa, H., Trout, T., Mueller, J., Wilhelm, S., Nelson, S., Soppe, R., and Shatley, D. 2002. Application of alternative fumigants through drip irrigation systems. Phytopathology 92:1349-1355.

Austerweil, M., Steiner, B., and Gamliel, A. 2006. Permeation of soil fumigants through agricultural plastic films. Phytoparasitica 34:491-501.

Baggio, J. S., Chamorro, M., Cordova, L. G., Noling, J., Vallad, G. E., and Peres, N. 2018. Effect of formulations of allyl isothiocyanate on survival of Macrophomina phaseolina from strawberry. Plant Dis. 102:2212-2219.

Bangarwa, S. K., Norsworthy, J. K., and Gbur, E. E. 2012. Allyl isothiocyanate as a methyl bromide alternative for weed management in polyethylene-mulched tomato. Weed Technol. 26:449-454.

Bangarwa, S. K., Norsworthy, J. K., Gbur, E. E., Zhang, J., and Habtom, T. 2011 Allyl isothiocyanate: A methyl bromide replacement in polyethylene-mulched bell pepper. Weed Technol. 25:90-96.

Borek, V., Morra, M. J., Brown, P. D., and McCaffrey, J. P. 1994. Allelochemicals produced during sinigrin decomposition in soil. J. Agric. Food Chem. 42:1030-1034

Boyd, N. S., Vallad, G., Wu, F., Noling, J., and Guan, Z. 2017. Placement of metam potassium in combination with dimethyl disulfide, chloropicrin, and 1,3-dichloropropene for Cyperus rotundus L. and broadleaf weed control in tomato (Solanum lycopersicum L.). Crop Prot. 100:45-50.

Brown, P., and Morra, M. 1996. Hydrolysis products of glucosinolates in Brassica napus tissues as inhibitors of seed germination. Plant Soil 181:307-316.

Castellá, G., Bragulat, M., Rubiales, M., and Cabanes, F. 1997. Malachite green agar, a new selective medium for Fusarium spp. Mycopathologia 137:173-178.

Dayton, D. M., Chaudhari, S., Jennings, K. M., Monks, D. W., and Hoyt, G. W 2017. Effect of drip-applied metam-sodium and $S$-metolachlor on yellow nutsedge and common purslane in polyethylene-mulched bell pepper and tomato. Weed Technol. 31:421-429.

Desaeger, J. A., Kenneth, W., and Csinos, A. 2008. Effect of application timing and method on efficacy and phytotoxicity of 1,3-D, chloropicrin and metamsodium combinations in squash plasticulture. Pest Manage. Sci. 64:230-238.

Drobnica, Ľ., Kristián, P., and Augustín, J. 1977. The chemistry of the-NCS group. Pages 1003-1221 in The Chemistry of Cyanates and Their Thio Derivatives: Part 2, Vol. 2. S. Patai, ed. John Wiley \& Sons Ltd., Chichester, UK.

EPA. 2018. Methyl bromide. United States Environmental Protection Agency https://www.epa.gov/ods-phaseout/methyl-bromide

Gilreath, J. P., Jones, J. P., Motis, T. N., Santos, B. M., Noling, J. W., and Rosskopf, E. 2003. Evaluation of various chemical treatments for potential as methyl bromide replacements for disinfestation of soilborne pests in polyethylene-mulched tomato. Proc. Fla. State Hortic. Soc. 116:151-158.

Gilreath, J. P., Santos, B. M., and Motis, T. N. 2008. Performance of methyl bromide alternatives in strawberry. HortTechnology 18:80-83.

Haar, M. J., Fennimore, S. A., Ajwa, H. A., and Winterbottom, C. Q. 2003. Chloropicrin effect of weed seed viability. Crop Prot. 22:109-115.

Hutchinson, C. M., McGiffen, M. E., Jr., Sims, J. J., and Becker, J. O. 2004 Fumigant combinations for Cyperus esculentum L. control. Pest Manage. Sci. 60:369-374.

Jenkins, W. R. 1964. A rapid centrifugal-flotation technique for separating nematodes from soil. Plant Dis. Rep. 48:692.

Kirkegaard, J. A., and Sarwar, M. 1999. Glucosinolate profiles of Australian canola (Brassica napus annua L.) and Indian mustard (Brassica juncea L.) cultivars: Implications for biofumigation. Aust. J. Agric. Res. 50:315-324

Komada, H. 1975. Development of a selective medium for quantitative isolation of Fusarium oxysporum from natural soil. Rev. Plant Prot. Res. 8:114-124.

Locascio, S., Dickson, D. W., and Mitchell, D. J. 2000. Chloropicrin enhancement of metam-sodium as an alternative to methyl bromide for mulched tomato. Proc. Fla. State Hortic. Soc. 113:198-200.

Mao, L. G., Wang, Q. X., Yan, D. D., Xie, H. W., Li, Y., Guo, M. X., and Cao, A. C. 2012. Evaluation of the combination of 1,3-dichloropropene and dazomet as an efficient alternative to methyl bromide for cucumber production in China. Pest Manage. Sci. 68:602-609.

McAvoy, T., and Freeman, J. H. 2013. Yellow nutsedge (Cyperus esculentus) control with reduced rates of dimethyl disulfide in combination with totally impermeable film. Weed Technol. 27:515-519.

Mithen, R., Faulkner, K., Magrath, R., Rose, P., Williamson, G., and Marquez, J. 2003. Development of isothiocyanate-enriched broccoli, and its enhanced ability to induce phase 2 detoxification enzymes in mammalian cells. Theor. Appl. Genet. 106:727-734.

Motis, T. N., Locascio, S. J., Gilreath, J. P., and Stall, W. M. 2003. Season-long interference of yellow nutsedge (Cyperus esculentus) with polyethylenemulched bell pepper (Capsicum annuum). Weed Technol. 17:543-549.

Noling, J. W., and Becker, J. O. 1994. The challenge of research and extension to define and implement alternatives to methyl bromide. J. Nematol. 26:573-586.

Norsworthy, J. K., and Meehan, J. T. 2005. Herbicidal activity of eight isothiocyanates on Texas panicum (Panicum texanum), large crabgrass (Digitaria sanguinalis), and sicklepod (Senna obtusifolia). Weed Sci. 53: 515-520.

Ren, Z., Li, Y., Fang, W., Yan, D., Huang, B., Zhu, J., Wang, X., Wang, X., Wang, Q., and Guo, M. 2018. Evaluation of allyl isothiocyanate as a soil fumigant against soilborne diseases in commercial tomato (Lycopersicon esculentum Mill.) production in China. Pest Manage. Sci. 74:2146-2155. 
Schneider, S. M., Rosskopf, E. N., Leesch, J. G., Chellemi, D. O., Bull, C. T., and Mazzola, M. 2003. United States Department of Agriculture-Agricultural Research Service research on alternatives to methyl bromide: Pre-plant and post-harvest. Pest Manage. Sci. 59:814-826.

USDA. 2010. Tomato statistics. United States Department of Agriculture Economic, Statistics and market Information System. https://usda.library.cornell.edu/ concern/publications/br86b356q?locale=en

Vallad, G. E., Freeman, D. J., and Dittmar, P. J. 2014. Vegetable and Small Fruit Production Handbook of Florida, 2014-2015. University of Florida, Gainesville, FL, U.S.A.

Vig, A. P., Rampal, G., Thind, T. S., and Arora, S. 2009. Bio-protective effects of glucosinolates-A review. LWT-Food. Sci. Technol. 42:1561-1572.

Wu, H., Zhang, G. A., Zeng, S., and Lin, K. C. 2009. Extraction of allyl isothiocyanate from horseradish (Armoracia rusticana) and its fumigant insecticidal activity on four stored-product pests of paddy. Pest Manage. Sci. 65:1003-1008
Yu, J., Boyd, N. S., and Guan, Z. 2018. Relay-cropping and fallow programs for strawberry-based production system: Effects on crop productivity and weed control. HortScience 53:445-450.

Yu, J., Land, C. J., Vallad, G. E., and Boyd, N. S. 2019a. Tomato tolerance and pest control following fumigation with different ratios of dimethyl disulfide and chloropicrin. Pest Manage. Sci. 75:1416-1424.

Yu, J., and Morishita, D. W. 2014. Response of seven weed species to corn gluten meal and white mustard (Sinapis alba) seed meal rates. Weed Technol. 28:259-265.

Yu, J., Sharpe, S. M., and Boyd, N. S. 2019b. Fumigant alone or in combination with herbicide for weed management in bell pepper (Capsicum annuum). Crop Prot. 118:31-35.

Yu, Q., Tsao, R., Chiba, M., and Potter, J. 2005. Selective nematicidal activity of allyl isothiocyanate. J. Food Agric. Environ. 3:218-221.

Zasada, I. A., Halbrendt, J. M., Kokalis-Burelle, N., LaMondia, J., McKenry, M. V., and Noling, J. W. 2010. Managing nematodes without methyl bromide. Annu. Rev. Phytopathol. 48:311-328. 